\title{
The Power of Market Intermediaries: From Information to Valuation Processes
}

\author{
Christian Bessy and Pierre-Marie Chauvin
}

\begin{abstract}
Sociology and economics tend to focus more and more on the intermediaries involved in economic and social relations, in the shape of distributors, matchmakers, consultants, and evaluators. Once they are distinguished according to their forms, their types of intervention and their effects, the intermediaries are a helpful category in order to study the social organization of markets as well as the changes that operate on them, especially regarding the social and economic values of goods, individuals and organizations. We discuss in the first section the link between intermediaries and information, through an analysis of the functions they fulfill that may explain their emergence, as well as the opportunistic behavior of intermediaries in relation to information flows. In the second section, we adopt a more pragmatist perspective on issues of valuation mainly based on "economics of convention", which emphasizes the collective dynamics of valuation. We show how intermediaries contribute to define valuation through their different activities and foster valuation frames that can improve the coordination of actors, but also reorganize the markets in different ways. We suggest an analytical distinction between the distribution, the temporality and the generality of the frames, and raise the issue of the valuation power of market intermediaries, their legitimation and the eventual regulation of their activities.

Key words: intermediaries; market; valuation; evaluation; convention; regulation

Sociology, economics and political sciences are becoming more and more interested in the "intermediaries" involved in economic, political, and social relations; these may take the form of organizations, service providers, experts, prescribers, and appraisers, as well as technical and
\end{abstract}

Christian Bessy, ENS Cachan / IDHE, 61, avenue du Président Wilson, 94235

CACHAN Cedex,FRANCE, bessy@idhe.ens-cachan.fr

Pierre-Marie Chauvin, Paris-Sorbonne University / GEMASS, 28, rue serpente, Maison de la Recherche, 75006 Paris, France,pmchanvin@gmail.com

(C) 2013 Christian Bessy and Pierre-Marie Chauvin

LiU Electronic Press, DOI 10.3384/vs.2001-5992.131183

http://valuationstudies.liu.se 
administrative mechanisms. This trend is a response to the changes impacting a reality that is more and more structurally complex, and in which the heuristic value of traditional categories and distinctions (state/market, individual/society, producer/consumer, etc.) is declining. This takes place within a configuration characterized by the increasing international circulation of goods, the liberalization of many activities and the encouragement of competition, as well as by the development of forms of organization by project (Boltanski and Chiapello 1999). These are all developments that currently offer multiple opportunities for intermediation. Remaining at this level of generality could lead to describing contemporary society as an "age of intermediaries." However, this general term covers entities with heterogeneous identities, roles, and impacts, which we differentiate here by analyzing and comparing research that has been devoted to them.

The economic activities of the intermediaries examined here consist in services relating to their participation in the construction, maintenance, or expansion of a market. We set focus on professional intermediaries considered as "third parties", which intervene between the so called "supply" and "demand", and whose actions have some effects on the economic or symbolic value of a product or an organization. Beyond the figure of the "auctioneer" traditionally acknowledged by the standard economic theory, we can identify four main types of intermediaries which are more or less linked to the supply or the demand side: the distributors that buy and resell products, the matchmakers that put into contact partners of exchange, the consultants that produce advice to their clients (generally from the "supply" side) and the evaluators that evaluate products, individuals or organizations. Each type of intermediary can potentially be involved in the activity of valuation (Dewey 1918), as well as being mixed in the "real" economic life. Following Dewey, we consider value as a rich empirical and observable fact that can take many forms (price, aesthetic value, reputation, status), and generally be defined as a "quality" attributed to an event, a situation, an object, an organization or a person, under some specific circumstances and with certain consequences. This pragmatist approach will lead us to focus more on the activity of valuation than on value itself and to observe which actors are decisive in the construction of economic and symbolic values on markets. Our main hypothesis is that intermediaries are the actors who, beyond their apparent specific function (providing services of buying and selling, matching, advising and evaluating), are all engaged in activities of valuation that shape the market.

It is an empirical question to know to what extent each particular intermediary carries out each kind of activity (selling, advising, matching, and evaluating) and to what extent its activities involves valuation. In other words, the so called "evaluators" (the fourth category in our typology) are not the only actors that produce 
valuations on markets, and the open definition of intermediary will help us show how (and what kind) of valuations are produced by these different types of intermediaries. If valuation can analytically be divided into the activities of evaluation (producing a judgment by assessing the value of something) and valorization (adding value to something), these two activities are often mixed in social processes of valuation (Beckert and Aspers 2011; Muniesa 2011; Vatin 2009).

This paper aims at discussing research belonging to two traditionally separated disciplines: economics and sociology. Aside from the development of interdisciplinary research, namely in the field of the so-called new economic sociology (Granovetter 1985; Swedberg 2003), few works simultaneously take both disciplines into account, while tackling the question of intermediaries. This cross-fertilization will allow us to highlight their active role in the dynamics of markets, through networks, cognitive frames, and valuation processes, traditionally studied by sociology, without neglecting the issues of coordination, calculus, and information, which are more analyzed by economics. This cross-approach has recently been adopted by the "actor-network theory" and the French school of "economics of convention" ("Economie des conventions") which both raised the question of how to create calculative devices which are competed in a "market for evaluations". This is in line with a widely shared statement saying that the market is not only the aggregation of a large number of singular transactions but also the frame defining the rules and the format of those transactions (Beckert 2009; Fligstein 2001; François 2010).

In pursuing these considerations, we seek to develop in this article the argument that intermediaries are not only platforms for putting economic partners into contact, but also active entities involved in the construction of markets and the dynamics of valuation that drive them. ${ }^{1}$ Hence, our preoccupation is not only the role of intermediaries in making goods calculable and in matching supply and demand, but also their impact on the cognitive categories and the values that order goods, people and organizations on markets.

To address these questions, we need to start by reviewing the emergence of intermediaries in economic research, a phenomenon that reflects a new understanding of information flows in markets. Thus, in the first section we discuss the link between intermediaries and information, through an analysis of the functions they fulfill that may explain their emergence, as well as the opportunistic behavior of intermediaries in relation to information flows.

\footnotetext{
1 This argument is also present in some recent works in political science, such as Nay and Smith (2002), who highlight the active role of political intermediaries in matching and formatting "institutional worlds" (instead of "markets" in the economic sociological approach).
} 
In the second section, we adopt a more pragmatist perspective on issues of valuation, mainly based on economics of convention, which emphasizes the collective dynamics of valuation and, in particular, the collective construction of criteria or principles of evaluation. Following this approach, valuations are not reduced to the resolution of information asymmetry problems, but raise the question of the definition of the relevant criteria used to judge or estimate. In the neoclassical approach of information search, these criteria are predetermined and remain unquestioned. Hence, the process of collective learning that leads to the relevant criteria is not taken into account.

Our position is that the two approaches are complementary in the study of the role of market intermediaries, even though the methods and the behavior hypotheses are different. Indeed, most economic approaches try to explain why intermediaries exist (by contrast with a purely individual information search in an anonymous market), why they differentiate themselves ("marketmakers" versus "matchmakers"), and why they can have a social efficiency. The move operated by economics of convention consists in a focus on the social relationships and dynamics that underlie the shared definition of valuation criteria, but also on the tools, devices and moral values that support the way economic actors and objects are valuated and qualified. As other pragmatist approaches, economics of convention leads to an extension of the list of (human and non-human) actors that participate in the construction of markets or "commercial channels". Our argument is that among these actors, intermediaries play a key role in the construction and/or the destabilization of these markets, due to their valuation power, and through their power of mediation between different logics, principles or worlds.

\section{Intermediaries and Information: Strategic Functions and Coordination}

How is the concept of intermediary situated with respect to traditional economic theory? Standard economic theory is based on the figure of the "auctioneer" whose primary function is to determine a fair price in the market. This fiction relies on the strict assumptions of the model of "pure and perfect competition." Questioning the assumption of complete and symmetric information has led to a renewed analysis of the role of market intermediaries and their emergence when opportunities for productive exchanges have not been exhausted. Through these configurations we can explain the appearance of new players aiming to take advantage of market features for personal gain and to engage in strategic activities, in the way Adam Smith pointed out in The Wealth of Nations.

After Smith's prefiguration, the elaboration of the role of intermediaries constitutes the starting point of the gradual 
development of marketing as a discipline distinct from economics in the early twentieth century. We can refer to the seminal work of Arch W. Shaw (1912), which analyzed the emergence and rise of middlemen by focusing on the organization of market distribution. Shaw identifies the general functions performed by the middleman: sharing the risk, transporting the goods, financing the operations, selling, assembling and assorting. As a result of the development of functional middlemen (insurance companies, direct transportation companies, banks), the author pays more attention to the function of selling (the communication of ideas about the goods) and the function of assembling and assorting, by analyzing the advantages to recourse (or not) to a middleman.

At the same time, marketing research has focused on the behavior of the consumer and, after the fifties, on how firms may seek to regulate demand by defining the target market or defining the optimal channel of distribution (Laufer and Paradeise 1982). Nevertheless, an author like Philip McVey (1960) criticizes the notion of "channel of distribution" in which manufacturers can easily choose between middlemen of many types and control them. Conversely, he analyzes channel-building from the standpoint of the middleman's relative capability of choice, while serving as purchasing agent for his customers rather than as selling agent for the manufacturer. From this more active approach to the role played by middlemen attached to their current customers group, McVey emphasizes the way they build some unusual product combinations or packaged assortments wellfitted to individual customers. In certain cases, the strength of the middleman is so great that it becomes impossible for a manufacturer to tap the market.

The emergence of intermediaries in the contemporary landscape of economic theory was first seen in research on labor markets, with the recognition of imperfect information (Stigler 1962). The presence of market intermediaries reduces the costs of the acquisition of information and, from a more institutionalist perspective, the transaction costs of negotiating and enforcing contracts (Williamson 1985). In the early 1960s, Stigler (1962) renewed the neoclassical economics tradition by emphasizing the costs of searching for information on the labor market. Searching is costly for both workers and employers, and in his view the raison d'etre of employment agencies arises from the imperfect character of the information that both sides can gather. More specifically, the concept of "asymmetrical information" was subsequently introduced into the study of other markets (Rubinstein and Wolinsky 1987, discussing financial intermediation). In particular, mention may be made of the secondhand goods markets, and Akerlof's famous article on the market for "lemons" (1970), in which product certification (which can be conducted by market intermediaries, among others) makes it possible 
to solve the problems of so-called "adverse selection" and therefore to avoid the gradual decline in the "quality" of goods offered for sale.

Thus, information imperfections are at the basis of economic models of intermediation that argue for the cost-effectiveness of an intermediary in a market. ${ }^{2}$ According to these models, the existence of intermediaries is a response to deficiencies in the market, or possibly an attempt to exploit these deficiencies. In the latter case, we can highlight their strategic intent. But empirical observation shows that a variety of intermediaries exists, which need to be differentiated in terms of the characteristics of the transactions concerned, and in particular by the level of uncertainty that surrounds them and that may call for the establishment of strong mutual trust between exchange partners.

\section{Responses to the Under-Investment in Information by Economic Agents}

The most common and simple idea present in the economic literature states that intermediaries, by setting prices and clearing market, providing liquidity and immediacy, matching and searching, guaranteeing and monitoring transactions, provide the underlying microstructure of most markets (Spulber 1996). We focus here on the two last functions assumed by intermediaries.

\section{Matching and Searching}

According to Autor (2008), discussing the labor market), if one believes that the proper functioning of a market is a public good that provides utility to both buyers and sellers, an outcome to be expected in a decentralized economy is one of under-investment on the part of economic agents in the production of this good. Individual agents cannot (or choose not to) bear the costs necessary for the production of perfect information, the result being substantial periods of search in the market (with the uncertainty that the search efforts of the agents may not result in a match) and problems of "adverse selection." Another source of inefficiency is the positive externalities that exist in the matching process. Indeed, an increase in the search intensity of one agent increases the probability of a match, hence the payoffs to the other agent who does not bear such information search costs. These

\footnotetext{
2 Another function of an intermediary is to coordinate the actions of members of a congested market. A current of economic literature has developed around the work of A. Roth (1994) who is interested in different labor markets in which a problem of coordination arises between employers and graduates of the university system (physicians, law clerks). Drawing upon the studies of Roth (2007) on kidney exchange clearinghouses, the work of P. Steiner (2008) on organ gifts shows all the complexity of such singular matches and the importance of social relationships in the working of such kind of an "arena".
} 
different inefficiencies could give rise to at least two kinds of intermediaries (Yavas 1992): "marketmaker" and "matchmaker", although there is considerable overlap in terms of the functions assumed by both. ${ }^{3}$ In different markets (stock, real estate, technology, used-car, and in a certain extent the labor market), the middleman can use "sell and buy" orders (as a matchmaker) to extract information about the demand and supply in the market and can use this information in choosing ask and bid prices (as a marketmaker).

\section{Guaranteeing and Monitoring Transactions}

As Stigler (1962) has focused on, information search does not only concern prices (distribution of wages) but also information on quality. Heterogeneity of quality leads to a consideration middlemen as experts or guarantors of quality. In his model, Biglaiser (1993) draws on the situation analyzed by Akerlof (1970), but restricts it to used durable goods, for which the buyer bears very high valuation costs. This justifies the use of a middleman who has invested in the relevant expertise and whose investment can be amortized by frequent transactions. The expertise gained by these intermediaries makes it possible to reduce valuation costs and can thus lead buyers to employ them in a cumulative process. We may note that in this model the expert has an incentive not to cheat by offering poor-quality goods, since the assumption is made that the expert's reputation is at stake. Biglaiser extends his model to retail and wholesale intermediaries which can offer many different products for sale. Consumers can also rely on the reputation of the intermediary without having to investigate the many product suppliers.

Specialized intermediaries can also reduce the problem of "moral hazards" in markets. As shown by Spulber (1996), when the actions of buyers and sellers are costly to observe, intermediaries provide monitoring and contracting services. For example, wine brokers intermediate wine exchanges between wine growers and merchants, or between merchants and merchants. They can earn returns through delegated monitoring by supervising suppliers for their customer. They also intervene as mediators who can help parties to adjust and solve conflicts (Baritaux et al. 2007).

Even though we focus on human intermediaries, one may notice that technological changes create new opportunities for intermediaries to exploit imperfect environments in which buyers and sellers meet,

\footnotetext{
3 This hybridity among marketing firms has early been underlined by McVey (1960).
} That raises the issue of their classification and statistical representativity. 
match, and negotiate. 4 From this point of view, the development of information and communication technologies (ICTs) promotes the emergence of intermediaries that enable market actors to reduce the costs of information search, including the costs of identifying potential partners. For example, the main function of job boards consists in posting job advertisements and building curriculum databases. Thus, internet-based labor market intermediaries allow multiplying job seeker/employer interactions (Marchal, Mellet, and Rieucau 2007).

\section{Distinguishing between Intermediaries in terms of Transaction Characteristics}

With a more institutionalist perspective, transaction cost economics (Williamson 1985) focuses on contractual problems arising from the management of the relationship between intermediaries and those who make use of their services. This approach leads to a distinction between intermediaries in terms of characteristics of transactions (such as the level of specificity, uncertainty, etc.) that have implications for the costs of measurement (the identification and evaluation of characteristics, and negotiation) and respect for "property rights" (compensation, resolution of disputes, and penalties). We only present here the functions of matching and valuation assumed by intermediaries, reminding that this approach has developed a wide literature on channels of distribution and in particular on franchising.

Following this perspective, Bessy and de Larquier (2001) have sought to model two types of matching, using the case of the labor market: standard matching, where the expectation of its ex post quality is highly reliable, based on knowledge of standard criteria shared by all participants in the market, and specific matching, which is more exposed to the hazards of the subsequent discovery of the level of quality which is subject to unique characteristics. If the matching is standard, an extensive search for information guarantees its quality, but if the matching is specific (or risky), intensive search is needed because a look at standard criteria of two potential partners may make them appear equivalent. One can thus distinguish between intermediaries who link together the standard supply and demand of qualities (or skills), and those who offer their clients the costeffectiveness of their ability to assess the "potential" of products (or individuals). These two reasons for the intervention of intermediaries (the facilitation of encounters and the assessment of quality) are linked

\footnotetext{
${ }^{4}$ By studying prominent digital intermediaries, a current of economic literature show how 'two-sided platforms' provide a technology for solving externality issue in a way that minimizes transaction costs. In these businesses (for example software platforms), pricing and other strategies are strongly affected by indirect network effects between the two sides of the platform. Indeed the pricing structure rebalances costs between the two sides by internalizing the indirect externalities (Hagiu 2007; Evans and Schmalensee 2005).
} 
to the degree of specificity and thus of risk in the matching process. This result implies that the market of intermediation is a segmented one, with some intermediaries seeking to differentiate themselves from the rest by means of a specific niche area of activity in which they will acquire a potentially significant expertise.

A similar analysis can be applied to "technology markets" and especially to the market for patents and licenses, which is characterized by high uncertainty about the value (or the 'strength') of intellectual property rights (IPRs) (Bessy 2006). In the case of "strong IPRs," where private actors envision increased possibilities for exchange between buyers and sellers of patents, they can position themselves as "license agents," participating in the development of the technology market by reducing transaction costs. Conversely, weaker IPRs increase the contractual risks and make it unlikely that a real technology licensing agent will become involved. Businesses will instead resort to alliances in the form of joint ventures. This can lead to the involvement of other intermediaries who facilitate alliances based on technological cooperation, by reducing the risk of opportunistic behavior.

The transaction costs approach allows distinguishing the activity of intermediaries according to the degree of specificity of the assets underlying the transaction. But its under-socialized vision of economic exchange leads to study the activity of intermediaries as a succession of calculation processes. This approach overlooks the way this activity is oriented by rules of interaction defined in reference to groups or relies on personal networks providing actors with credible information.

\section{The Go-Betweens: Trusted Resources for Innovative Activities}

The intermediaries analyzed in these various studies may be specialized agencies whose primary activity is bringing business partners together and evaluating quality, or other organizations carrying out mediating activities secondary to some other primary activity. In these situations, the activities are generally combined to benefit from economies of scope. In the case of technology markets, those involved may be banks or venture capital companies, consulting and technology transfer 
agencies, professional organizations, law firms specializing in corporate law, ${ }^{5}$ or firms in some other sector.

With respect to the labor market, professional organizations can also play a role as recruitment and training intermediaries (Bessy and Marchal 2009). But actors further removed from the workings of the labor market may also be involved in hiring, within the frame of their innovating activity. Research by Chauvin (2010b) on Bordeaux wines has shown, for example, how consultants in the wine trade who initially intervene with the goal of improving the quality of the wines may also be asked to do some recruiting for the wine producers. One can also quote the example of software engineering companies, who may approach talented young people with very specific expertise on behalf of their clients (Bessy and de Larquier 2001). Beyond the immediate reduction in the costs of recruitment, they guarantee the ability of these candidates to develop innovations in areas with a high degree of uncertainty, because of their own reputation as experts in the field. These temporary intermediaries are trusted resources, and it is important to examine more generally how this trust is built up.

The work of Nooteboom (2000) shows how important the gobetween is in creating innovation-oriented alliances. This analysis can be extended to the search for partners in any business project, where each party needs to be sure of the "quality" of all the others. Beyond the claims of transaction cost economics about the role of arbitration by a third party in resolving disputes, Nooteboom presents a series of additional arguments. The intermediary can assess the relevance of the information transmitted by each party to the transaction and then inform each one separately in such a way that none of them reveals what they know to any of the others. This makes it possible to control the dissemination of information. Moreover, the intermediary can help build mutual confidence early in the cooperation process, due to the transitive character of trust relations. It may also help to end the alliance by making it more progressive.

These temporary intermediaries are hardly taken into account by the "search approach" in which economic agents make a rational calculus of information search, in particular in order to assess the option of trading through a middleman. Now it happens that a large

\footnotetext{
5 Suchman (2000) has shown how the corporate law firms in Silicon Valley have substantially contributed to its development, not only through innovations in contract matters (funding of software companies by venture capitalists), but also by providing guarantees of the quality of the parties concerned, and even by putting them into contact. These "local intermediaries" are consultants, disseminators of contractual and informal standards, gatekeepers, and matchmakers. This type of actor is on the fringe of the category of market intermediary, because it is not lawyers' primary function to create matches; however, they contribute largely to the construction of the venture capital market that finances high-tech companies, and to the related law market, building on their reputation within networks of social relations.
} 
share of exchange opportunities are the by-products of other economic activities or result from people being embedded in on-going networks of interaction oriented towards economic and non-economic goals (Granovetter 1995).6 Such an intermediary can put different networks in touch with each other, thus counteracting excessive narrowness, which can make networks rigid and too closed. Beyond innovative activities, personal networks provide actors with credible and trustworthy information in markets in which there is no obvious device to judge quality (Karpik 2010).

\section{The Strategic Behavior of Intermediaries}

With a more strategic perspective, one may find the argument for the strength of "weak ties" (Granovetter 1973) in the theory developed by Burt (2000) concerning the "network entrepreneur". He shows how, in a world where information plays a vital role in the accumulation of wealth, informational advantage can be obtained by connecting entities that were previously separated (the "structural holes"). Burt adopts Simmel's concept of the tertius gaudens or "third who benefits," to describe the role that gives one player the opportunity to intervene between two others or to play each of them off against the other. According to Burt, the power of the intermediary consists in the possibility to control the interactions or the networks of separated social actors. This control derived from "structural holes" is uncertain and the power of the intermediary only gives him "chances of success" depending on the tensions between non-redundant relationships. Burt's analysis also explains that "network entrepreneurs" seek to accumulate reputation advantage through multiplying the number of links, but only to the extent of being suspected to act strategically.

The lack of powerful reputation mechanisms can give rise to more "opportunistic" behavior on the part of intermediaries that are officially recognized in the market. Based on a model developed by Hart and Kreps (1986) for speculative activity, Lesourne (1991) distinguishes between intermediaries involved in the proper functioning of the market (convergence towards a "stable" market in which all the possibilities for making good matches have been exhausted) and those whose more strategic behavior is intended to "destabilize" the market.

Gautié, Godechot, and Sorignet (2005), who have observed the highly competitive and specialized activity of headhunters in the executive job market, also emphasize the role of strategic behavior. To be sure of completing the desired task quickly, the headhunter preselects one or two "clones" and surrounds them with two or three

${ }^{6}$ We may also note that Rees (1966) has particularly emphasized the importance of networks of interpersonal relationships for guaranteeing the quality of candidates recruited in the labor market. 
atypical profiles; the clients, convinced by this grouping of the scarcity of the kind of professionals they are looking for, make a decision more quickly than when faced with five identical individuals-and in favor of the "clone". In the same way, in a very competitive context, headhunting agencies help to partition and segment the market by creating sets of employment categories, as well as contributing to salary inflation. Here we see that beyond matchmaking, headhunters are in a position to fix prices in the market and can act as salary consultants, helped in this by new information technologies.

We find the same kind of strategic opportunities in marketing methods. It does seem true that contemporary modes of representation in advertising create an illusion of exclusivity or of scarcity (Appadurai 1986), but other methods such as merchandising and building assortment, in which the process of sorting is fundamental, entertain a more subtle game with categories of products. As Azimont and Araujo (2007) show from their analysis of category review meetings between manufacturers of fast-moving consumer goods and retailers, these actors permanently negotiate the definition of categories of products. They can also play strategically with these categories by relying on conventions about consumers' representations of categories. Misleading advertising and the sale of counterfeit products represent the extreme cases (and legally reprehensible) of strategic use of these conventions and in particular of those on which brands work (Bessy and Chateauraynaud 1995).

\section{Towards a Pragmatist Approach of the Valuation Power of Intermediaries}

As the transaction costs economic approach shows, the existence of quality standards is conducive to the development of the activity of intermediaries that operate on wide markets. In their absence, matching rely on more specific forms of intermediation or on the intervention of experts who bring trust pledges, or on networks of personal relationships. As we have seen with Burt's analysis, these networks of relationships can be instrumentalized by "intermediaries". These strategic opportunities not only show the more active role of intermediaries in market shaping, but also their strategic behavior relying on conventions about the quality of products (or individuals) that they have themselves contributed to build.

The purpose of this section is, precisely, to provide a better understanding of these conventions, the evaluation frames they underpin, and the role played by the different market intermediaries in their genesis, diffusion and stabilization. That raises the issue of their valuation power and their legitimation. Once these conventions (setting common computing spaces) are stabilized, intermediaries can play their traditional role highlighted by the economic theory based on information search, or arbitrate between becoming a marketmaker or 
a matchmaker. Hence, this section moves from a view of intermediaries as informational platforms to a conception of actors whose effects go beyond mere intermediation in the narrow sense, covering not only information but also the dynamics of valuation in the relevant markets.

Since the beginning of the 1990s, "economics of convention" has demonstrated the crucial role of intermediaries in the functioning of markets (Bessy and Chateauraynaud 1995; Bessy and EymardDuvernay 1997). Through their activities of search and selection, and the nature of the relationships they sustain with sellers and buyers, they contribute to the social construction of markets and to the dissemination of the conventions or standards of quality that underpin them. The analysis in terms of "quality convention" allows formalizing the different processes by which product (or organization) characteristics can be defined, and as a result limit uncertainty about the agents' behavior (Eymard-Duvernay 1989) ${ }^{7}$. Thus, the market is not given a priori, but is constructed by means of "third parties" who can be more or less stable and institutionalized, and who can structure various modes of activity or introduce mediation between general conventions of quality and more local conventions. From an empirical standpoint, this approach investigates the entire available body of instruments and mechanisms, and in particular cognitive artifacts such as the classifications and nomenclatures, advertisements, and assessment tests used by intermediaries in their daily work, which play a role that is both cognitive and normative in directing their activity.

This idea is in line with one of the key arguments of the approaches in terms of "distributed cognition" (Hutchins 1995) and "sociology of translation" or "actor-network theory" (Callon 1986; Cochoy and Dubuisson-Quellier 2000; Mallard 2000; Cochoy 2002; Callon and Muniesa 2005). According to Callon (1986, 185), intermediaries take on diverse forms, generating an activity of intéressement, defined as "the group of actions through which one entity ... strives to create and stabilize the identity of the other actors that it defines through the way it defines the problem". In a later paper, Callon (1991, 134) defines an intermediary as "anything passing between actors which defines the relationship between them". They include literary

\footnotetext{
7 In particular, Eymard-Duvernay (1989) refers to the "orders of worth" distinguished by Boltanski and Thévenot (2006) in their model of justification of actions in the public arena. In this perspective, the decision to conform to a given convention is not reduced only to calculation, but may also consider the legitimacy of the actions prescribed by this convention, by making value judgments about them.

8 The aim of these investigations is to put forward the distribution of knowledge among individuals and between them and their socio-physical environment. The unit of analysis is thus no longer the individual or the social group, but a physical and cognitive system composed of individuals and the artifacts they employ.
} 
inscriptions, technical artifacts, human beings and money in all its forms. His general thesis is that intermediaries both order (by describing) and form (by being involved in relationships) the "medium of the networks they describe" (Callon 1991, 135) $)^{9}$. Callon and Muniesa (2005) especially highlight the effects of such actors on goods and the way people produce, manipulate and choose them: these activities imply a series of operations resulting in the "calculability of the good". This idea is also developed by Beunza and Garud (2004) in a stimulating paper focusing on the role of Wall Street securities analysts as "frame-makers". These works show that intermediaries are not only go-betweens or even transformers of knowledge, but are themselves entrepreneurs in action. They move back and forth between different social worlds. Far from only transferring knowledge in one direction, they are engaged in an exchange of knowledge through moving between places (Meyer 2010). Hence, the word transfer does not do justice to the practices of knowledge brokers, that can be better understood with the concept of "translation" 10 which implicates an actual transformation of arrangements of human and non-human actors.

We want first to highlight how frames of valuation are both used and created or modified by intermediaries by developing more precisely the point of view of "economics of convention" on valuation and intermediaries. Unlike actor-network theorists, ${ }^{11}$ we will keep the term "intermediaries" while highlighting the active role they play in markets, but we will distinguish different types of intermediaries regarding the type of role they play in such worlds. Then, we propose a characterization of their power of valuation according to the nature of the valuation frame they produce, which can be more or less general/particular, more or less distributed/concentrated, and more or less durable/ephemeral.

\footnotetext{
9 He then introduces a "purely practical" (Callon 1991, 141) distinction between intermediaries and actors by providing different definitions of what an actor is. An actor is "an intermediary that puts other intermediaries into circulation" (Callon 1991, 141), actors are "those who conceive, elaborate, circulate, emit, or pension off intermediaries". In other words, intermediaries are simple links between entities whereas actors transform the world through the expected and unexpected consequences of their actions.

10 The notion of "translation" has been introduced by Callon (1984), who identified four "moments" of translation: "problematisation", "interessement", "enrolment" and "mobilisation".

11 The word "intermediary" itself is criticized by proponents of this theory. Intermediaries do not add anything new or different to the existing state of affairs; they merely transfer information or knowledge. By contrast, mediators make a difference via translation processes whose outcome cannot be predicted from the original conditions.
} 


\section{The Four Types of Intermediaries and Their (Creative) Use of Frames of Valuation}

Every activity of valuation is based upon some "frames", which are the (more or less) shared cognitive scheme that organize the valuation experience. Beyond the empirical and local statements made by some scholars about the framing role of specific types of intermediaries (such as Beunza and Garud [2004] about securities analysts as "framemakers"), we will show that the four types of intermediaries identified in the introduction are implied in valuation frame-making and frameusing activities.

\section{Distributors}

Trade intermediaries, traditionally considered as buying and selling platforms, can be analyzed as entrepreneurs of new models of distribution that have some consequences on frames of valuation, which consist more precisely here in the ways products are valorized in commercial channels. New modes of valorization are often linked to a material and immaterial framing of the market situation (Kjellberg and Helgesson 2007; Cochoy 2010) that goes beyond the traditional marketing activity of targeting customers.

For example, Antoine Bernard de Raymond (2007) shows how French mass-market retailing is the product of different evolutions that create opportunities for new intermediaries: the transformations of traditional retail selling and deep changes in supplying facilities, the appearance of a global rationality of the circulation of products based on the optimization of transport flows and a strict packaging chain with strict sanitary conditions. Frames of evaluation can here be thought of with the help of Boltanski and Thévenot's theory of "cités" (2006), these cognitive worlds in which actors use some principles of action and justification. In the case of mass-market retailing, the "industrial logic" is at the heart of the transformation of traditional production and distribution of goods (based on "domestic logic") as shows the passage from "camenbert normand" to "camembert normé" (Boisard and Letablier 1987) which follows its mass-distribution by reorganizing thoroughly the logistics (in particular the way milk is collected) and by redefining the links with farmers.

The mass-distribution case also shows the proliferation of different service providers that do not buy or sells the goods (as retailers and wholesalers do), but various services performed like warehousing, transports, merchandising, and different kinds of consultancy, which play a role in the down-stream valuation process of products.

A second example of this active role of trade intermediaries in the determination of frames of evaluation can be found on the art market. Art dealers not only assess the value of artists by using existing and predetermined valuation frames (made by museums or critics for 
example), they participate in constructing these frames through their engagement in the birth of artistic movements, aesthetic conventions but also "price conventions" that circulate on markets. Velthuis (2005) shows, for example, that in a social configuration characterized by radical uncertainty on the quality of goods, intermediaries such as art dealers are likely to create convention-based prices. These conventions are linked to specific commercial channels of the contemporary art market in which dealers share the same conception of artistic work, and can then coordinate their activities with other agents of the commercial channel: artists, collectors... Velthuis identifies three main prices "narratives" or conventions that have been created and used in the art market since the 1950s: "honorable prices" stand for the postwar gallery circuit which was confined to a limited art connoisseurs circle; "superstar prices" are characteristic of the 1980s New York boom in which prices were rising tremendously high; "prudent prices" account for the more cautious commercial scene in the late 1990s in which galleries became real "companies". These types of prices are cognitive tools that shape the meaning of the historical development of the art market, but they are also normative devices that allow art dealers to justify their practices and to compare with competitors. "Distinguishing different prices is a means for art dealers to express the values they endorse in their business life" (Velthuis 2005, 141).

This research highlights the plurality of valuation conventions within a single market and the fact that some specific frames of valuation are linked to some specific commercial channels. If intermediaries are the actors that make this link between commercial channels and valuation conventions possible, they may combine these various conventions in some different ways, and foster through their "friction" or their "dissonance" new valuation forms or principles (Stark 2009).

\section{Matchmakers}

A second category of intermediaries includes the actors that are paid to put two (or more) different parties into contact. This fundamentally "relational" activity is not only a question of relationship and flows of information, it is also an issue of cognitive frames and valuation. A good example of empirical research is to be found in the work of Bielby and Bielby (1999) on talent agencies in the American television market. They show how, in this labor market, "matchmakers" do not simply bring together television channels and program directors and producers. Their activities go further by creating "packages" of teams which include producers, scriptwriters, directors, and actors, in order to offer turnkey projects to the TV channels. ${ }^{12}$ Thus, they construct a singular product by combining resources in an innovative way and

12 This argument is in line with the prior analysis of McVey (1960). 
participating in the segmentation of the professional world in which they operate. Hence, intermediaries' activities produce categorizations that contribute to the cognitive segmentation of markets. As we showed in the first section, intermediaries can play a role in expanding the equivalencies employed in this categorization and, conversely, by reducing them so as to create "artificial scarcity" (Gautié, Godechot, and Sorignet 2005). This strategic way of playing with conventions of quality is all the more likely to occur if the market is increasing in scale and the demand-side clients have little expertise in this sphere.

Such an analysis is indeed useful to understand the activity of labor market intermediaries. Their intense activity of putting partners in touch leads them to develop valuation frames and categorizations of jobs and skills, which are all the more used by these intermediaries than they become stable conventions that allow a plurality of actors to coordinate with one another. Besides, the reflection about intermediaries proposed by the "economics of convention" started with a focus on how conventions of skills are embedded in the different devices used by the recruiters on the labor market: want advertisements, tests, graphology analysis, nomenclatures and classifications of profession (Bessy and Eymard-Duvernay 1997; Bessy et al. 2001). The studies of the long-term evolution of such devices in France show that the private employment agencies participated in valorizing the logics of "skills" and "employability". This leads to a valuation of the most general aptitudes of individuals to the detriment of the collectively negotiated employment classifications in specific sectors which are considered unsuitable to the new flexible organization forms (Boltanski and Chiapello 1999).

The search for skill transferability is in line with the possibilities generalist agencies have of presenting a "very competent" individual to a wider scope of potential recruiters. The creation and the diffusion of a new form of categorization or valorization can rely on a critical work of traditional valuation frames, but also on a more progressive and incremental process linked to an entrepreneurial, innovative and lucrative activity. In terms of convention dynamics, job agencies carry the representations of employers and workers that claim for a recognition of their individual skills, but they also create and spread their own valuation tools that contribute to the individualization of employment relationships. Hence, frames of valuation can be fostered by different kinds of economic actors on the job market, including groups of workers, employers, and professional intermediaries. This case raises two main questions: the question of the imputation of a new valuation frame to an actor (or a group of actors) and the question of the collective acceptance by a majority of actors. According to "economics of convention", the intermediary is generally considered as the actor that gives the initial impulse to the valuation convention, and its collective acceptance may be linked to the social 
legitimacy of the convention (Boltanski and Thévenot 2006) or different kinds of mimetic processes (Orléan 2011). The case of fashion is a good illustration of these different processes by which valuation conventions are collectively accepted.

The ethnographic research of Ashley Mears (2011) on fashion models helps to understand how an "original look" appears and is valued through a mimetic process. This process is engaged by most reputed model agents that support some specific types of models. However, they cannot act only on their own: to avoid a too big price difference between models, agents often consult each other to set up "fair" prices, and conventions of prices and looks emerge from their interactions. This is in line with the argument raised by Velthuis (2005) concerning the art dealers trying to keep up their legitimacy by dealing with different commercial and aesthetic conventions. Moreover, these strategic interactions whether in fashion or in art spheres, are likely to take place during trade shows.

\section{Consultants}

Even when they do not participate directly in some economic transactions, consultants may contribute to the definition of some valuation frames for products or job candidates. We can give the example of the style bureaus of the fashion trend such as it is reported by Rinallo and Golfetto (2006). These authors show how the material, cognitive and interactive dimensions of some trade shows (like "Première Vision") help conventions (on future styles) to be spread and valued within the clothing fabric industry, and more generally within creative industries. At the beginning, these conventions are issued from a process of discussion between French and Italian manufacturers considered to be the most innovative. They answer to a very fragmented textile industry and to the need to reduce the uncertainty about the qualities of textile products (color, structure, aspect, touch, decoration, and treatment). This reduction of uncertainty may improve the coordination between the different actors. Nevertheless, if the identification of the future trends is proposed by the internal experts of producers (members of "Première vision"), the authors point out the crucial role played by style bureaus in this process. These companies are specialized in trend forecasting and they operate in different creative industries. They can be considered as "brokers of language" as they connect material properties of clothes and symbolic meanings about products. This connecting activity contributes to the "bodily anchorage" of conventions (Bessy and Chateauraynaud 1995).

Generally speaking, once they have invested in the design of a valuation frame, consultants try to spread it within an economic sector or in different economic fields. A good illustration could be the consultant agencies in employment and salaries, which set up 
definitions of positions that stand for a whole range of companies, at the least for the biggest ones, in order to establish a salary hierarchy.

Reynaud (1992) showed that this kind of consultant agencies had to carry out surveys in order to gather information about the salaries in each company. In order to do so, they have to transform the information they have gathered into comparable items: the value of surveys depends on equivalence decisions between positions for which names differ. Moreover, their clients do not receive passively the results of the surveys, they adapt their strategies to these results and to the norms they have contributed to build. By this mechanism, the activity of consultant agencies has some consequences on the work organization and the salary practices of their clients, and they participate in building the economic value attributed to their employees. Reynaud interprets the role of the consultant agencies as a kind of "Walrasian auctioneer" that organizes the "tâtonnement" and that serves as intermediaries between the companies and the market considered as a set of socially constructed information. We may add that they contribute to the cognitive segmentation of the market by creating some new valuations conventions of workers and positions. These conventions are all the more powerful as they are followed by the companies that were not in the panel of the survey.

This power of valuation can also be attached to a "signature" that the consultant uses as a more or less explicit strategic tool. The wine consultants can for example be valued through their "oenological signature" (Chauvin 2010b), which recently entered the repertoire of valuation frames for wines. This signature consists in the type of intervention in the wine estates (regular/occasional), the type of public presentation of the consultant (discrete/visible) and the way it is associated with products (strongly/weakly), and the qualitative style of the wines he or she contributes to produce. Even though a signature is a source of reputation that can be transferred to products, it is an asset that consultants have difficulty assuming because of the importance of the soil and vintage in the making of reputations in the French wine industry.

The main question raised by these examples is the imputation of the responsibility of a particular consultant (or consultant agency) in the emergence of a new valuation frame or a new category of goods, in contrast to the case of a distributed building among a plurality of consultants and other intermediaries.

\section{Evaluators}

If the three previous types of intermediaries carry out activities that have some consequences in terms of valuations, their core activity does not explicitly consist in producing evaluations, rankings or ratings. However, we can now identify and analyze a fourth type of intermediaries whose main activities precisely rely on producing such 


\section{Valuation Studies}

devices. There is a growing amount of works focusing on such actors and their effects, as western contemporary societies can be thought as audit societies (Power 1999), in which financial, medical, technological, environmental, quality, and many other types of evaluations are produced by a set of professionalized actors. Espeland and Sauder (2007) proposed to conceptualize such actors as "third parties" that foster some social "reactivities" in the worlds they evaluate. They especially focus on the third parties in the education sector, that is to say actors that are neither suppliers nor demanders of education goods, for example education media. Such actors produce some rankings that create or reinforce some criteria of valuations (number of students, number of international scientific prizes, students' professional careers etc.) that can become "conventional" in the field. These conventions of valuation are interiorized by the majority of evaluated actors, who may modify their organizational and communication strategy to conform as well as possible to the criteria fostered by the rankings. This case accounts for the possible instrumentalization of the valuation criteria by the evaluated actors, but also for the difficulty to escape from the "discipline" of rankings. These effects raise the social issue of the negative or "bad" conventions that are created or spread within the academic world but also in the financial world (Orléan 2011) and many others.

"Bad" as well as "good" effects of valuations are not necessarily the product of an explicit strategy and can emerge progressively through unexpected social mechanisms. The activity of the wine critic Robert Parker is a good case for understanding how a powerful evaluator may foster "despite himself" some new conventions and categorizations on the wine market. If he deliberately created and spread an innovative format of wines valuation (a 50-100 point quality scale), he also fostered some more informal and unintended categories of valuations within this economic world. While arguing for his "prescriptive" recommendations in terms of the information he provided to consumers, he assigned points and made judgments that, once adopted and "interpreted" in the oenophile community, gave rise to new categorizations, of which he himself may have been a target (Chauvin 2010a).

The controversial category of "Parkerized wines" is a good illustration of this, and shows how an intermediary can become the source of retroactive implementation of the strategies of some wine producers. The unanticipated effect of the intermediary's activity in this case is the producers' introduction of new production methods with the goal of improving their standing in the Parker ratings. On a meso-level, this can contribute to a new configuration of the conventions of quality in the considered market. This case shows that the strategic valuation activities of intermediaries are themselves 
subject to new interpretations and unforeseen categorizations made by other market players.

Despite their professional heterogeneity, these four types of intermediaries share a common characteristic, which is not a substance or a fixed identity but is based on the dynamics they foster: the power of valuation of an intermediary can be measured through the effects of the valuations it produces, whatever their forms or their logics may be.

\section{Intermediaries' Power of Valuation: Definition, Generality and Temporality}

As long as their role as prescribers is recognized (Benghosi and Paris 2003), market intermediaries can have a prominent part in the creation and the dissemination of conventions and the resulting categorization of goods, people and organizations. All intermediaries do not have a strong valuation power. Generally speaking, power is an unequally distributed resource, and it is an empirical question to assess to what extent each intermediary enjoy this specific kind of power. However, we can suggest some distinctions and analytical tools in order to identify some important factors that lead to these asymmetrical situations. At the end of this sub-section, we will also propose a picture synthesizing the three main characteristics of the valuation frames and the way they can help to categorize the different examples of intermediaries referred to in our paper.

\section{The Definition of the Valuation Frame: Distributed versus Concentrated}

As we have already mentioned (concerning the consultants), one may distinguish two polar cases of the definition of the valuation frame. First, valuation frames may come from a plurality of intermediaries that share the same conception of what constitutes the value of a product. Second, they may result from the activity of a single and dominant intermediary (a high standard consulting job agency, a famous flying winemaker, or a reputed model agent) that succeeds in spreading to his or her clients what is worth or what is valued in a specific field. So, the definition of the valuation frame is more or less distributed between different intermediaries.

We can note that in the former case, the power of valuation is often attached to a professional status that confers a symbolic authority. In the latter case, the legitimacy of the intermediary may be less stabilized and protected than the one attached to a professional group, and leads him or her to make a permanent "reputational work" (Zafirau 2008). Thus, according to Rinallo and Golfetto (2006), the ability of the producers in the textile and clothing industry (members of "Premiere Vision") to represent the market and to make it real is attributed, in line with a Bourdieusian argument, to the differences of "symbolic capital". This specific kind of capital depends on the particular 


\section{Valuation Studies}

characteristics of each market, and is often linked to the temporality of the "entry" on the market. The first intermediaries who can be identified and collectively recognized as innovators, can progressively acquire the legitimacy and the status of "pioneers" and can impose new trends to the "followers" of the markets.

The Generality of the Valuation Frame: Standard versus Singular The valuation power of intermediaries can also be analyzed through the degree of generality of the frames they contribute to elaborate.

First, it seems important to distinguish the intermediaries who build the market by centralizing and reallocating the information through standardized categories of quality, and those who generally act at a local level, every matching being different from the other ones, according to a negotiation process of the quality that occurs during the evaluation. This latter case is more interesting to analyze with a pragmatist approach, as standardized and centralized valuation processes are by definition less interactional and uncertain in their progress.

Recruitment processes in the field of highly innovative jobs give a good illustration of the situations in which the skills of the candidates or the relevant qualities of the product emerge from an interactive process of information exchange (Bessy 1997). The client firm and the intermediary learn from the $\mathrm{CV}$ of the candidates the ins and outs of the job searched and the required skills. The candidates try, from their part, to profile their experience and their skill according to the specificity of the potential employer. In this case, intermediaries are involved in a highly distributed and negotiated valuation process, in which every actor influences the other one. Commenting the works of Kreiner (2007) on architecture competitions, Stark (2011) identifies the same kind of interactive process of redefinition of the principles of evaluation during the competition process. The projects of the competitors also serve to better define the real problems that have to be solved, as well as the operational principles for a successful performance.

Stark notices that this implies a shift from the resolution of an analytical problem (for example through the analysis of standard matching in transaction costs approach) to questions of interpretations (which could be developed in a conventionalist and pragmatist approach of specific matching), which can be thought of with the help of Dewey's pragmatist approach, according to which the relevant valuation principles are generally built during the evaluation process. This more interactional and uncertain evaluation process is likely to be present in the beginning of the development of a new activity or a new technology. 


\section{The Temporality of the Valuation Frame: Short-Term versus Long-Term}

The distinction between standardized and singular matches can be completed by a close look at the "temporal" dimension of the valuation power.

Markets distinguish themselves by combining, differently, various kinds of temporal valuation frames. In a first perspective, one may link some particular markets with some specific temporal frames: for example, the financial market has become a short-term valuation sphere, according to a vast literature on financial evaluators. Work by Montagne (2009) shows, for example, how the increased delegating of investment funds management has contributed to creating a professional services market (consultants, managers, appraisers, and rating agencies) and standards methods of scoring and pricing (Beunza and Garud 2004). Parallel with this standardization, their activity is likely to entrench the short-term as the dominant economic timeframe. The increased importance of consultants and various other intermediaries with the job of measuring performance has created two kinds of constraint for financial management companies-quantitative (performance markers) and qualitative (organizational audit)-as well as systematizing competition. As Montagne states (2009, 8), "the creation of a market in valuation, affecting both managers and appraisers, is thus directly responsible for the standardization of methods of valuation and for their alignment with short-term investment methods." Intermediaries are thus not external actors, but impact directly on the dynamics of valuation by shortening its timeframe.

A second approach may try to identify how different types of temporal valuation frames are articulated in the same market and what role intermediaries play in these temporal "frictions". For example, if fashion trends are short-term valuation frames that are supposed to be renewed each year, one may try to identify how they are linked with more stabilized valuation frames. On the fashion market, these frames could be the "names" of the fashion houses which give a kind of "status depth" to this market, by transferring their longer, more stable worth to the other "names" or "products" of the market. On the French wine market, if official classifications represent long-term valuation frames (in the both sense of stable frames and frames whose legitimacy is linked to their longevity), they are challenged by other types of frames, especially the annually renewed rates given by critics. Intermediaries such as wine critics not only convey new short-term temporal frames, but they have to deal with long-term frames (by respecting them and showing they just produce marginal newness), and they can paradoxically reinforce them by their work (Chauvin 2010a). Our distinction between short-term and long-term valuation frames is a schematic way of analyzing the 


\section{Valuation Studies}

plurality of temporalities involved in economic worlds. Further work may take advantage of the important sociological literature which deconstructs the idea of "time" or "temporality" by identifying the various forms of temporalities that structure social life (Fine 1990; Flaherty 2003).

In order to sum up our results, table 1 (below) is an attempt to classify the different examples quoted until now, according to the criteria we have used to characterize valuation frames. 


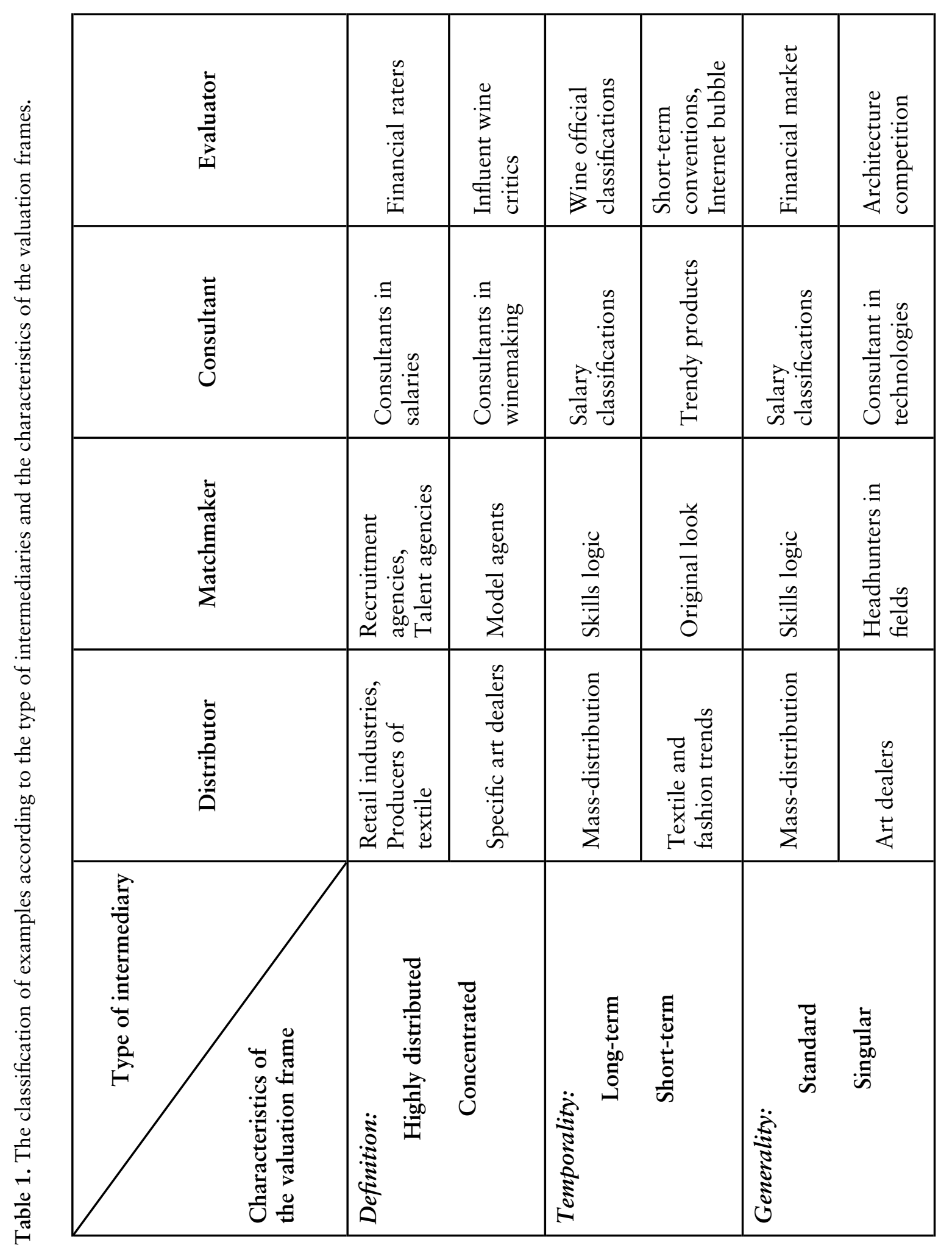




\section{Valuation Studies}

The first criteria, based upon the type of definition of the valuation frames, concerns actors, whereas the two others (the temporality and the generality) concern more the valuation frames and their "social forms". When we combine the three criteria (distribution, temporality, generality), we can distinguish between two stylized configurations.

The first configuration involves powerful intermediaries, stable and standard frames. In this case, intermediaries have a strong power of valuation because they are at the origin of the definition of the valuation frames, which are not negotiated in situations and are persistent over time.

The second configuration consists in less powerful intermediaries, negotiated and singular frames. In this case, intermediaries have less power because the valuation frame is defined among many actors, constantly negotiated and relevant only during the time of the valuation process. Intermediaries adopt local conventions which emerge from the valuation process, and none of the intermediaries has a dominant role. Obviously, there is a continuum between these extreme cases, along which the various empirical cases could be distributed. Beyond the examples quoted in this paper, our hypothesis is that all intermediaries can be located in this kind of table. One may think of empirical cases such as matchmakers on the "online dating" market. The websites analyzed by Cornwell and Lundgren (2001), Bergström (2011) or Kessous (2011) are intermediaries which participate in constructing the "value" of the potential partners, through the selection criteria of the partner (age, sex, location, but also social, cultural and economic characteristics), the type of access to the different areas of the website, the type of evaluation of previous partners that can display the members of the website, and the visibility offered to some particular members who appear on the main page of the website. If we follow our typology, this kind of intermediary could be analyzed as a "distributed" case (Bergström studies for example more than one thousand websites). The two other characteristics of the intermediaries (the temporality and the generality of the frames they produce) would probably be "short-term" (because of the frequent change of the selection criteria displayed by the websites and the rapidity of the production and publication of an evaluation by members) and "singular" (because of the specific criteria displayed by the websites according to ethnic or religious parameters for example). The analytic fecundity of this typology could be illustrated by many other examples from different markets.

\section{Explaining and Regulating the Valuation Power of Intermediaries: Two Challenging Tasks}

The characterization of the valuation frames fostered and used by intermediaries is helpful to understand their activity and how they shape value dynamics on market. However, it may not be enough to 
explain their unequal valuation power, as they do not all have such effects on their economic world. A few sociological theories can be useful to solve this problem by focusing on different legitimatizing sources: the "symbolic capital" (Bourdieu 1993) of the intermediary, the legitimacy of the convention used by the actors (Boltanski and Thévenot 2006), or a network of aligned actors that is produced by different operations of mediation (Latour 2005). These different approaches of legitimacy can be considered as alternatives (Lamont 2012), but a clear-cut distinction of this kind may be difficult to make in empirical markets, as the case of the fashion trends analyzed by Rinallo and Golfetto (2006) shows it. The question of explanation of the diffusion of conventions represents a problem that goes beyond the scope of this paper, and that would need to be developed in further research.

The second question is the corollary of the power of intermediaries: if their actions have some effects on the social worlds they are involved in, one may study the nature of the transformations they foster, and what kind of control or regulation one may organize to limit their "negative" or "pernicious" effects. The conventionalist approach can give some analytical tools to answer some sociopolitical questions such as the "financial crisis" by highlighting the role of the intermediaries in the creation, the diffusion and the transformation of conventions in crisis' dynamics. In fact, intermediaries' interventions can weaken the financial system because of the difficulty to attribute some responsibilities to the multiple concerned actors. The proliferation of financial intermediaries and products has made it much more difficult to determine liability during the recent financial crisis (Montagne 2009). Cervone's work on credit rating agencies shows for example how difficult it is to assign liability for errors or fraud to valuation intermediaries. She points out that, especially in the American context, investors who filed lawsuits for damages involving erroneous assessments made by credit rating agencies had their suits dismissed. In a recent article (Cervone 2010), she advocates the adoption of a strict liability regime, rather than yet more regulation of the activity of these agencies. Krebs (2009) and Tuch (2010) also underlined the power and the role of credit rating agencies during the current economic crisis by showing that their judgments and evaluations are far from neutral and that their impact as "reputational intermediaries" needs some kind of regulation.

In contrast, Orléan (2009) shows that these rating agencies are only the bearers of valuation conventions (the interpretation of underlying market trends) in place at a given point in the financial markets, which all stakeholders (both issuers and investors) agree to adopt. It is thus the market itself that constrains the rating agencies. Orléan concludes: "In my opinion there is no evidence that anything like a rating agency independent of the market could exist. For that to happen, it would 


\section{Valuation Studies}

have to derive its income from a source that was itself independent, yet without seeming to be a foreign body with no legitimacy in the eyes of the investors. Is this not trying to square the circle?" (Orléan 2009, 68). Liability, then, is spread across all the players in the financial system, making it problematic to attempt to impute liability to any individual.

There are many other domains in which the regulation of the evaluators' activities could play an important role. The research led by Demailly and Maroy (2004) about the regulation of the educative system in Europe shows, for example, how some new types of intermediaries both evaluate and control educative organizations and institutions. The rise of "post-bureaucratic" institutional settings, such as the ex post control exerted by evaluators, or the ex ante socializing action on the professionals (teachers and administrative staff), implies new types of cross-regulation between states, educative institutions, and the new "transnational" intermediaries. These intermediaries, who generally come from teaching, become either "experts in rationalization", "agents of proximity", or "political executives". According to our typology, they can be classified as "evaluators", but the diversity of their status should not be overlooked, because it can explain why organizations aimed at regulating these intermediaries only exist in an embryonic form.

Concerning matchmakers and consultants, as they defend the interest of the parties they represent as well as their self-interest, this issue of the regulation of their activities is at stake. ${ }^{13}$ That raises also the question of the drawing up professional-ethics rules to guarantee that experts in the concerned fields will be reasonably disinterested and will avoid conflicts of interests. Besides, these intermediation activities can be a source of "boundary struggles" (Lamont and Molnar 2002) between different professions or professional territories which are arbitrated by public authorities (Abbott 1989). Whereas Economic theory designs regulation of professions mainly in reference to the concepts of "asymmetrical information" (between the professional and its client) and "externality", our notion of "power of valuation" proposes another way to cope with this issue that would need further development.

\section{Conclusion}

New developments in economic theory justify the emergence of intermediaries by their role in reducing the costs of information search, or more generally the transaction costs. In this perspective, intermediaries generally improve the functioning of markets. More

13 Lizé, Naudier and Roueff (2011) emphasize the problem of the legal qualification of "intermediary" which cannot be, in the case of the French Law, both "third party" and "party" to a contractual relationship. 
precisely, intermediaries often add value to products by supplying information and guaranties or by increasing their availability (Spulber 1996). This analysis of the market microstructures offers a better understanding of the real workings of markets by highlighting the different roles played by intermediaries which are not limited to the sole function of pricing. But this added value is reduced to a potential increase in the utility of goods for consumers, the definition of individual preferences remaining exogenous. There are few economists who take into account the endogeneity of preferences or even the collective construction of valuation (such as graduates in the Spence signal theory, Spence 1973), so leaving a large part of collective valuation processes unexplored.

The pragmatist approach presented in our paper completes the perspectives in which intermediaries are rather a passive role of information platform. In particular, economics of convention shows how intermediaries contribute to define valuation frames through their different activities and instigate conventions that can improve the coordination of actors in markets, but also reorganize the markets in different ways. The analysis of valuation conventions may provide a better understanding of the strategic behavior of market intermediaries which is intended to "destabilize" the market. This approach is consistent with previous studies highlighting how market intermediaries could be more than passive classifiers, especially through the concept of "frame-makers" suggested by Beunza and Garud (2004).

The four types of intermediaries identified in this article allow us to underline that the dynamics of valuation frames constitute an important dimension of the activity of so-called "evaluators", but also of the activity of "distributors", "matchmakers" and "consultants". Moreover, we propose a characterization of these valuation frames according to the nature of their definition (more or less distributed), their generality and their temporality.

Once they have been differentiated in terms of their effects, intermediaries can be a good empirical entry to study the social organization of markets as well as the changes occurring in them, including changes in the social and economic value of goods, individuals, and organizations. Besides, these changes raise the issue of the valuation power of market intermediaries and the eventual regulation of their activities. 


\section{Valuation Studies}

Acknowledgments. We are grateful for the very insightful comments and suggestions made by the two anonymous reviewers of our paper. In response to an earlier draft, Pierre François, Kevin Mellet, Olivier Roueff and Rainer Diaz-Bone provided useful suggestions that we are happy to acknowledge here. In addition, we thank Constance Georgy for her helpful review of the last version of the article. The contents are the authors' exclusive responsibility.

\section{References}

Abbott, Andrew. 1989. The System of Professions: An Essay on the Division of Expert Labour. Chicago: University of Chicago Press.

Akerlof, George. 1970. “The Market for 'Lemons': Quality Uncertainty and the Market Mechanism." Quarterly Journal of Economics 84 (3): 488500 .

Appadurai, Arjun. 1986. "Introduction: Commodities and Politics of Value." In The Social Life of Things: Commodities in Cultural Perspective, edited by Arjun Appadurai, 3-63. New York: Cambridge University Press.

Autor, David. 2008. "The Economics of Labor Market Intermediation: An Analytic Framework." IZA Discussion Paper No. 3705, introductory chapter of Studies of Labor Market Intermediation, edited by David Autor, 1-32. Chicago: University of Chicago Press.

Baritaux, Valérie, Magali Aubert, Etienne Montaigne, and Hervé Remaud. 2007. "Matchmakers in Wine Marketing Channels: The Case of French Wine Brokers.” Industrial Organization, EconWPA.

Beckert, Jens. 2009. "The Social Order of Markets." Theory and Society 38 (3): 245-269.

Beckert, Jens, and Patrick Aspers. 2011. "Value in Markets." In The Worth of Goods: Valuation and Pricing in the Economy, edited by Jens Beckert and Patrick Aspers, 3-38. Oxford: Oxford University Press.

Benghozi, Pierre-Jean, and Thomas Paris. 2003. "De l'intermédiation à la prescription: le cas de l'audiovisuel." Revue française de Gestion 402 (49): 205-227.

Bergström, Marie. 2011. "La toile des sites de rencontres en France. Topographie d'un nouvel espace social en ligne.” Réseaux 166 (2): 225260.

Bessy, Christian. 1997. "Cabinets de recrutement et formes d'intermédiation sur le marché du travail." In Les intermédiaires $d u$ marché $d u$ travail, edited by Christian Bessy and François Eymard-Duvernay, 103-141. Paris: PUF.

- 2006. "Organisations intermédiaires et accords de licence de technologie." Revue d'Economie Industrielle 116: 71-104.

Bessy, Christian, and Francis Chateauraynaud. 1995. Experts et faussaires. Pour une sociologie de la perception. Paris: Métailié. 
Bessy, Christian, and François Eymard-Duvernay, eds. 1997. Les intermédiaires $d u$ marché du travail. Paris: PUF.

Bessy, Christian, François Eymard-Duvernay, Emmanuelle Marchal, and Guillemette de Larquier. 2001. Des marchés du travail équitables? Une approche comparative France/Royaume-Uni. Brussels: P.I.E.-Peter Lang.

Bessy, Christian, and Guillemette de Larquier. 2001. "IT Professional wanted (£25,000+benefits) / Entreprise recherche informaticien diplômé des Grandes Ecoles." In Des marchés du travail équitables? Une approche comparative France/Royaume-Uni, edited by Bessy and al., 227-268. Brussels: P.I.E.-Peter Lang.

Bessy, Christian, and Emmanuelle Marchal. 2009. "Le rôle des réseaux et des marchés dans les recrutements." Revue Française de Socio-Economie 3: 121-146.

Beunza, Daniel, and Raghu Garud. 2004. "Security Analysts as FrameMakers." Economics Working Papers 733, Department of Economics and Business, Universitat Pompeu Fabra. Revised Sep 2005.

Bielby, Denise D., and William T. Bielby. 1999. "Organizational Mediation of Project-Based Labor Markets: Talent Agencies and the Careers of Screenwriters." American Sociological Review 64 (1): 64-85.

Biglaiser, Gary. 1993. "Middlemen as Experts." RAND Journal of Economics 24: 212-223.

Boisard, Pierre, and Marie-Thérèse Letablier. 1987. "Le camembert: normand ou normé; deux modèles de production dans l'industrie fromagère." Cahiers du Centre d'Études de l'Emploi, Paris: PUF, 30: 130.

Boltanski, Luc, and Eve Chiapello. 1999. Le nouvel esprit du capitalisme. Paris: Gallimard.

Boltanski, Luc, and Laurent Thévenot. (1991) 2006. On Justification. Economies of Worth. Princeton: Princeton University Press.

Bourdieu, Pierre. 1993. The Field of Cultural Production. New York: Columbia University Press.

Burt, Ronald. 2000. “The Network Entrepreneur." In Entrepreneurship, edited by Richard Swedberg, 281-307. Oxford: Oxford Management Readers.

Callon, Michel. 1986. "Eléments pour une sociologie de la traduction." L'année sociologique 36: 169-208.

- 1991. "Techno-Economic Networks and Irreversibility." In A Sociology of Monsters? Essays on Power, Technology and Domination, edited by John Law, 132-161. London: Routledge.

Callon, Michel, and Fabian Muniesa. 2005. "Economic Markets as Calculative Collective Devices.” Organization Studies 26 (8): 1229-1250.

Cervone, Elisabetta. 2010. "Credit Rating Agencies: Do We Need Draconian Oversight?" EALE, European Association of Law and Economics, 27th Annual Conference in Paris, Working Paper.

Chauvin, Pierre-Marie. 2010a. Le marché des réputations. Une sociologie du monde des Grands Crus de Bordeaux. Bordeaux: Féret. 


\section{Valuation Studies}

2010b. "La signature œnologique. Frontières et transferts de réputation chez les consultants vitivinicoles.” Sociologie du travail 62 (4): 461-479.

Cochoy, Franck. 2002. "Une petite histoire du client, ou la progressive normalisation du marché et de l'organisation." Sociologie du Travail 44 (3): 357-380.

—. 2010. "Reconnecting Marketing to 'Market-Things': How Grocery Equipments Drove Modern Consumption.” In Reconnecting Marketing to Markets: Practice-Based Approaches, edited by Luis Araujo, and Hans Kjellberg, 29-49. Oxford: Oxford University Press.

Cochoy, Franck, and Sophie Dubuisson-Quellier. 2000. "Les professionnels du marché. Vers une sociologie du travail marchand." Sociologie $d u$ Travail 42 (3): 359-368.

Cornwell, Benjamin, and David Lundgren. 2001. "Love on the Internet: Involvement and Misrepresentation in Romantic Relationships in Cyberspace vs. Real Space." Computers in Human Behavior 17: 197211.

Demailly, Lise, and Christian Maroy. 2004. "Les régulations intermédiaires des systèmes éducatifs en Europe: quelles convergences?" Recherches Sociologiques 35 (2): 5-24.

Espeland, Wendy Nelson, and Michael Sauder. 2007. "Rankings and Reactivity: How Public Measures Recreate Social Worlds." American Journal of Sociology 113 (1): 1-40.

Eymard-Duvernay, François. 1989. "Conventions de qualité et formes de coordination.” Revue Economique 40 (2): 329-359.

Evans, David S., and Richard Schmalensee, 2005. "The Industrial Organization of Markets with Two-Sided Platforms." In NBER Working Papers, $\mathrm{n}^{\circ} 11603$.

Fine, Gary Alan. 1990. "Organizational Time: Temporal Demands and the Experience of Work in Restaurant Kitchens.” Social Forces 69 (1): 95114.

Flaherty, Michael. 2003. "Time Work: Customizing Temporal Experience." Social Psychology Quarterly 66 (1): 17-33.

Fligstein, Neil, 2001. The Architecture of Markets: An Economic Sociology of Twenty-First-Century Capitalist Societies. Princeton: Princeton University Press.

François, Pierre. 2008. Sociologie des marchés. Paris: Armand Colin.

Gautié, Jérôme, Olivier Godechot, and Pierre-Emmanuel Sorignet. 2005. "Arrangement institutionnel et fonctionnement du marché du travail. Le cas de la chasse de tête." Sociologie du travail 47 (3): 383-404.

Granovetter, Mark. 1973. "The Strength of Weak Ties." The American Journal of Sociology 78 (6): 1360-1380.

. 1974. Getting a Job: A Study of Contacts and Careers. Chicago: University of Chicago Press.

- 1985. "Economic Action and Social Structure: The Problem of Embeddedness." American Journal of Sociology 91 (3): 481-510. 
Hagiu, Andrei. 2007. "Merchant or Two-Sided Platform?" Review of Network Economics 6: 115-133.

Hart, Oliver, and David Kreps. 1986. "Price Destabilizing Speculation." Journal of Political Economy 94 (5): 927-52.

Hutchins, Edwin. 1995. Cognition in the Wild. MIT Press.

Karpik, Lucien. 2010. Valuing the Unique: The Economics of Singularities. Princeton: Princeton University Press.

Kessous, Emmanuel. 2011. "L'amour en projet: Internet et les conventions de la rencontre amoureuse." Réseaux 166 (2): 191-223.

Kjellberg, Hans, and Claes-Fredrik Helgesson. 2007. "The Mode of Exchange and Shaping of Markets: Distributor Influence on the Swedish Post-War Food Industry.” Industrial Marketing Management 36 (7): 861-878.

Krebs, Joshua. 2009. "The Rating Agencies: Where We Have Been and Where Do We Go From Here?" The Journal of Business, Entrepreneurship and the Law 3 (1): 132-164.

Kreiner, Kristian. 2007. "Architectural Competitions: Empirical Observations and Strategic Implications for Architectural Firms.” Nordic Journal of Architectural Research 21 (2-3): 37-51.

Lamont, Michèle, and Virag Molnar. 2002. "The Study of Boundaries in the Social Sciences." Annual Review of Sociology 28: 167-195.

Lamont, Michèle. 2012. "Towards a Comparative Sociology of Valuation and Evaluation." Annual Review of Sociology 38: 201-221.

Latour, Bruno. 2005. Reassembling the Social: An Introduction to ActorNetwork-Theory. New York: Oxford University Press.

Laufer, Romain, and Catherine Paradeise. 1982. Le Prince bureaucrate. Paris: Flammarion.

Lesourne, Jacques. 1991. Economie de l'ordre et du désordre. Paris: Economica.

Lizé, Wenceslas, Delphine Naudier and Olivier Roueff, eds. 2011. Intermédiaires $d u$ travail artistique: A la frontière de l'art et $d u$ commerce. La documentation Française, Questions de culture.

Mallard, Alexandre. 2000. "La presse de consommation et le marché. Enquête sur le tiers consumériste." Sociologie du travail 42 (3): 391-411.

Marchal, Emmanuelle, Kevin Mellet, and Géraldine Rieucau. 2007. "Job Board Toolkits: Internet Matchmaking and Changes in Job Advertisements." Human Relations, 60 (7): 1091-1113.

McVey, Philip. 1960. "Are Channels of Distribution What the Textbooks Say?” Journal of Marketing 24 (3): 61-65.

Mears, Ashley. 2011. "Pricing Looks: Circuits of Value in Fashion Modeling Markets." In The Worth of Goods: Valuation and Pricing in the Economy, edited by Jens Beckert and Patrick Aspers, 155-177. Oxford: Oxford University Press.

Meyer, Morgan. 2010. "The Rise of the Knowledge Broker." Science Communication 32 (1): 118-127. 


\section{Valuation Studies}

Montagne, Sabine. 2009. "Le court-termisme institutionnalisé: les effets de la gestion de portefeuille déléguée." Revue d'Economie Financière, special issue: 417-432.

Muniesa, Fabien. 2011. "A Flank Movement in the Understanding of Valuation." The Sociological Review 59: 24-38.

Nay, Olivier and Andy Smith. 2002. "Les intermédiaires en politique: médiations et jeux d'institutions." In Le gouvernement $d u$ compromis, edited by Olivier Nay and Andy Smith, 47-86. Paris: Economica.

Nooteboom, Bart. 2000. Inter-Firm Alliances, Analysis and Design. London: Routledge.

Orléan, André. 2009. De l'euphorie à la panique: comment penser la crise financière. Paris: Editions Rue d'Ulm.

— 2011. L'empire de la valeur-Refonder l'économie. Paris: Seuil.

Rees, Albert. 1966. "Labor Economics: Effects of More Knowledge. Information Networks in Labor Markets." American Economic Review Papers Proceedings 56 (2): 559-566.

Reynaud, Bénédicte. 1992. Le salaire, la règle et le marché. Paris: Christian Bourgois.

Rinallo, Diego, and Francesca Golfetto. 2006. "Representing Markets: The Shaping of Fashion Trends by French and Italian Fabric Companies.” Industrial Marketing Management 35 (7): 856-869.

Roth, Alvin, and Xiaolin Xing. 1994. "Jumping the Gun: Imperfections and Institutions Related to the Timing of Market Transactions." American Economic Review 84 (4): 992-1044.

Roth, Alvin. 2007. "Repugnance as a Constraint on Markets." Journal of Economic Perspectives 21 (3): 37-58.

Rubinstein, Ariel, and Asher Wolinsky. 1987. "Middlemen.” The Quarterly Journal of Economics 102: 581-593.

Shaw, Arch. 1912. "Some Problems in Market Distribution." The Quarterly Journal of Economics 26 (4): 703-765.

Spence, Michael. 1973. "Job Market Signaling." The Quaterly Journal of Economics 87 (3): 355-374.

Spulber, Daniel. 1996. "Market Microstructure and Intermediation." The Journal of Economic Perspectives 10 (3): 135-152.

Stark, David. 2009. The Sense of Dissonance. Princeton: Princeton University Press.

- 2011. "What's Valuable?" In The Worth of Goods: Valuation and Pricing in the Economy, edited by Jens Beckert and Patrick Aspers, 319338. Oxford: Oxford University Press.

Steiner, Philippe. 2008. "Le marché comme arène et les technologies sociales d'appariement.” Sciences de la société 73: 41-62.

Stigler, Georges. 1962. "Information in the Labour Market." Journal of Political Economy 70: 94-105.

Suchman, Mark. 2000. "Dealmakers and Counselors: Law Firms as Intermediaries in the Development of Silicon Valley." In Understanding 
Silicon Valley: The Anatomy of an Entrepreneurial Region, edited by Martin Kenny. Stanford: Stanford University Press.

Swedberg, Richard. 2003. Principles of Economic Sociology. Princeton: Princeton University Press.

Vatin, François, ed. 2009. Evaluer et valoriser: Une sociologie économique de la mesure. Toulouse: PU Mirail.

Williamson, Oliver. 1985. The Economic Institutions of Capitalism: Firms, Markets, Relational Contracting. New York: Macmillan, The Free Press.

Yavas, Abdullah. 1992. "Marketmakers versus Matchmakers." Journal of Financial Intermediation 2: 33-58.

Zafirau, Stephen. 2008. "Reputation Work in Selling Film and Television: Life in the Hollywood Talent Industry." Qualitative Sociology 31: 99127.

Christian Bessy is currently attached to IDHE (Institutions and Dynamics of Historical Economics) as a CNRS researcher (Centre National de la Recherche Scientifique). He is also a lecturer at the "Ecole Normale Supérieure de Cachan". He is specialized in institutional economics, law and economics, recruitment and labor market intermediaries, knowledge transfer and intellectual property rights. He has published many books and articles on these subjects.

Pierre-Marie Chauvin is an associate professor of sociology at ParisSorbonne University with a joint affiliation to the GEMASS (Groupe d'Etude des Méthodes de l'Analyse Sociologique de la Sorbonne). His research interests include economic sociology, sociology of reputations and status hierarchies, sociology of time and visual sociology. He is the author of several publications on the valuation processes within the wine industry. 